\title{
The Analysis of Challenges on Value Added Tax Administration in Ethiopia: Evidence from Wolaita Zone, Sodo City Administration
}

\author{
Samuel Semma Waje \\ Lecturer at Infolink College Wolaita Cumpus, Ethiopia \\ Alemayehu Elda Ergo \\ Assistance professor, $\mathrm{PhD}$ candidate, Lecturer at Wolaita Sodo University, Ethiopia
}

\begin{abstract}
All countries in the world whether developed or developing generate most of their government's revenues from taxes. Value Added Tax (VAT) is one means of income generation for the government of Ethiopia and its administration is at its infant stage. The study has focused on classifying the key challenges that distressing VAT administration in Soddo city in wolaita zone in Ethiopia. The identified challenges in this study are awareness, tax technology applications, VAT evasion, VAT audit and enforcement, service delivery, tax administration simplicity, and Fairness. Descriptive research method and stratified simple random sampling techniques were employed and Statistical Package for Social Science (SPSS) version 20 soft ware employed to gather data. Respondents who have been participated in the study were mainly VAT registered business firms. The findings of the study show that awareness of the society, tax technology, VAT evasion, tax audit and enforcement, VAT administration simplicity challenges are significantly affected performance of VAT revenue administration in the Sodo City. Finally based on the results, possible solutions were given. These are the authority should conduct a regular awareness creation programs to update the business firms, develop taxpayer identification and registration, decrease VAT evasion activities, and establish effective audit and enforcement mechanisms. The business firms have to obey the current Ethiopian VAT rules and regulations and start to work in cooperation with the authority in fighting against those business firms that violate the rules and regulations of VAT.
\end{abstract}

Keywords: Ethiopia, Challenges, Value added Tax, Descriptive analysis

DOI: $10.7176 /$ RJFA/11-9-05

Publication date:May $31^{\text {st }} 2020$

\section{Introduction}

Value Added Tax (VAT) is a percentage tax on a value added applied at each stage of production. It is a type of indirect tax; currently found in more than 130 countries and has become the main source of revenue. (Keen, Lockwood, 2007). The main reform to indirect taxation was the introduction of VAT in January 2003. However, weak tax administration, particularly in developing and transitional economies is the principal impediment to the successful implementation of VAT. Value added tax was invented because very high sales taxes and tariffs encourage cheating and smuggling (Worku, 2008). One of the mechanisms in which countries raise revenue to finance government spending on the goods and service that most of government uses as tool taxation.

In comparison to the less developed countries, the developed countries have more ability to collect significant revenue through imposing of taxes. One of the reasons for this has been the well organized and effective tax system operating in the developed countries unlike the developing countries' economies which are characterized by weak monetization and the less development of the formal sectors. The symptoms such as low economic efficiency, less administrative simplicity, inflexibility, less political accountability and fairness problems characterized in developing countries. The tax system need to be economically efficient meaning the tax system should not have an impact on the allocation of resources. As Abraham Tesfaye, 2003 explained taxpayers ought to be able to determine what they are actually paying so that the political system can more accurately reflect the preferences of individuals (Abraham Tesfaye, 2003).

In view of the importance of Value added Tax/VAT/ administration and Collection, many studies have been conducted in developing countries with respect to VAT administration tasks and its challenges. These studies include Clement,2009),(Kerver,2008),(Abraham,2003),(Herouy,2004),(WollelaA,2008),(Taye 2011). These papers assessed the VAT administration in developing and administration challenges and reflection problems and prospects of implementing VAT in Ethiopia and others developing countries(Taye, 2011).This research identified the challenges that affect the performance VAT Revenue collection in Ethiopia, Wolaita Zone, Sodo city administration Revenue Authority.

\subsection{Statements of problems}

In Ethiopia, VAT collection faces diverse internal and external tax collection challenges and issues. Ethiopian 
Revenue Minister (ERM) has identified low performance of VAT revenue targets and the actual amount collected. This means that ERM has not been achieving an acceptable degree of tax compliance from a fast growing taxpayer population. It has been reported that tax evasion remains particularly high creating a need to improve the situation(Jalata, 2014).In numerous under developing countries like Ethiopia, the low revenue yield of taxation can only be attributed to the fact that the tax administrations systems are not adjusted, tax provisions are not properly enforced because of either on the fact of the inability to collect VAT or on corruption reasons. But the challenges of tax administration on the other side of the system get low attention. (Tulu, 2007 ).

Different researches and studies made internationally in the title of VAT. To mention some of them, the internal factors affecting performance of the collection of local value added tax revenue(Karanja, 2012), tax policy challenges facing in developing countries(Kayanga, 2007), identifying the effective factor for the improvement of tax compliance (Mahmoud Moeinadin, 2014 ). Nationally also there also studies have been made. To mention some of them VAT implementation and its related problems conducted by (Mamo 2011), the impact of Electronic Tax Register on Value Added Tax conducted by (Taye 2011), determinants of Taxpayers' voluntary compliance with Taxation (Tulu 2007 ).

The Sodo City Revenue Authority collects taxes from individual taxpayers and property in its territory authorized by the Proclamation No 285/2002 the Federal Inland Revenue Authority (FIRA) to administer the VAT. Due to different factors the Revenue Authority cannot collect the potential tax which the zone can generate. For instance, out of 746 VAT registered business firms 351(47\%) were nil filers as july to September 2019.This indicates that large portion of VAT tax payers were not paying (file zero) Value added tax to government. This made the performance of VAT collection to be low. This indicates that still more has to be done in order to increase the performance of VAT revenue collection. There are different challenges which affect the performance of VAT administration in Sodo city in the Wolaita Zone. The expected challenges include awareness of the society about VAT, improper usage of electronic Tax register machines or less tax technology usage, Tax evasion, Tax audit and enforcement, Service delivery system of the authority for their customers, administrative simplicity, flexibility and fairness challenges are some of the signs poor tax administration. It is unable to collect and administer the potential tax from VAT registered firms in Sodo city in the Zone. This is the problem that needed to be studied. (Wolaita zone Revenue Authority, 2018)

\subsection{Objectives of the study}

\subsubsection{General objective}

The main objective of this study is to investigate challenges that affecting the Performance of Value Added Tax Administration in Sodo city in Wolaita zone.

\subsubsection{Specific objectives}

Specifically this study tries to address the following issues:

- $\quad$ To identify demographical characteristics of VAT registered firms.

- $\quad$ To identify the main challenges affecting the performance of VAT administration.

\subsection{Scope of the study}

The scope of the study is limited to VAT only; it did not consider other types of taxes. In addition, it is conducted in Ethiopia, Wolaita zone Sodo city Revenue authority.

\section{Literature Review}

\subsection{VAT and its Development in Ethiopia}

The Ethiopian government has launched Tax Reform Program (TRP). Value added tax /VAT/ as part of the tax reform program. The tax reform program (TRP) was continued by establishment of a new Ministry of Revenue as a first step to advance tax administration and collections and to contest tax evasion in the country. (Ethiopian Revenue annual report, 2019) Next to the reform of tax system various tax policy measurements were undertaken. These were: the increase in the sales tax; a new legislation on presumptive taxation and a 5 percent withholding tax on imports became effective in February 2001; tax identity number (TIN) in March, 2001 and the tax reform task force was established and the new tax revenue agency was re-established; Again the next to the above improvements, VAT legislation was approved by parliament in October 2001 and implemented in January 1, 2003. A revised income tax law has been approved and made operational. This revised law includes enhanced enforcement procedures and an improved penalty regime, with a view to increasing the efficiency of income tax collection, and ensuring the recovery of income tax arrears(Taye, 2011).

The Ethiopian government has made the first move to a number of tax reform mechanisms. (Africa Development Bank, 2003). These mechanisms include the design and computerization of the taxpayer registration process; the operational development of taxpayer services activities, return process and debit and audit activities; publicity campaign and taxpayer education. These mechanisms are expected to progress the government's revenue collection and its administration efficiency. It was planned that the VAT was applicable 
on those taxpayers that meet the minimum threshold of 500,000 Birr and above in annual turnover, and the tax payers were mandatory pay 15 percent tax every transaction. (Yalemtesfa, 2011).

\subsection{Review of previous studies on Ethiopia}

In the Ethiopian circumstance, inadequate works have been conducted in the area of value added tax administration challenges related with the title of factors that affect VAT revenue collection performance especially in wolaita zone. But the researcher have found that some studies that indirectly associated with this research.These studies include the Yalemtesfa Taye (2011) assessed the impact of electronic tax register on VAT; Markos abraha (2010) assessed VAT administration and revenue collection and its challenges and opportunities. Hailemariam Mamo (2011) emphasized on implementation of VAT, and Teklu Kasu (2011) focuses on challenges of tax administration of VAT. Thus, this particular section provides a detailed review of the two (three) related studies conducted in the context of Ethiopia.

A study made by Teklu (2011) assessed the challenges of tax administration of VAT in Arada sub city of Addis Ababa. The findings of the study showed that lack of well trained and credible tax officials mainly in tax payers' identification and registration process; lack of well trained officials to use SIGTAS (Standard Integrated Government Tax Administration System) so not possible to know the exact number of active VAT registrants, to identify and control non filers. Yalemtesfa (2011) also assessed the effectiveness of Electronic Tax Registers (ETRs) in the processing of Value Added Tax. The paper sought to determine the effect Electronic Tax register effect on administration cost and compliance cost, the extent of tax evasion while using ETRs and audit follow up effects. Hailemariam (2011) alerted particularly on identifying and assessing the problems rose in association with the implementations of VAT by the Ethiopian Revenue and Customs Authority. The finding of the paper identified the main problems that encountered are: misunderstanding of the public in general and business community in particular regarding the VAT laws, resistance against registrations for VAT by some traders, administration inefficiency from ERCA, provisions of understated financial statements, and non-issuance of invoices or issuance of illegal invoices exercised by registered business enterprises.

\subsection{Conclusions and knowledge gap}

As per the review of the literature most of the empirical studies that have been conducted with the aim of identifying factors affecting the performance VAT administration belong to European Union and some countries such as India, Iran, Keniya and South Africa. Moreover, the literature review also reveals the existence of controversial conclusions that results from different studies made so far. Furthermore, so far as the review of the literature discloses, very scanty work has been done with the objective of identifying the challenges that affecting VAT revenue collection Ethiopia in particularly in Sodo city in wolaita zone. In the context of Ethiopia, the related study conducted by Teklu (2011) mainly assessed the challenges of tax administration in Arada sub city, Addis Ababa, Ethiopia. This study clearly fails to fill the knowledge gap that exists in the area as far as it considers only very few internal variables and ignores all the external variables affecting VAT collection performance.

Markos Abraha (2010) examined Value Added Tax (VAT) Administration and Revenue Performance: Challenges and Opportunities in the Mekelle Branch the Ethiopian Revenue and Customs Authority (ERCA). Hailemariam Mamo (2011) also studied the Implementation of Value Added Tax and its related problems in Ethiopia. Hailemariam also fails to disclose the knowledge gap that exists in the area and overlooked some important variables that can significantly affect the performance of VAT revenue collection from the point of view of the theories and previous empirical studies reviewed above. In addition to this, the study fails to disclose the impact of some very important variables on VAT revenue collection such as awareness of the society, tax evasion and political factors among others.

In general, the lack of sufficient research on the collection of VAT in the context of Ethiopia and the existence of knowledge gap in the area initiate this study. Therefore, the objective of this research is to examine the challenges that affect the performance of VAT revenue collection in wolaita zone and to fill the knowledge gap that exists in the area.

\subsection{Conceptual Framework}

This study proposed that VAT revenue collection is determined by awareness of people about VAT, the technological system, Tax evasion, Tax administrative simplicity, Tax Audit and Enforcement and service delivery and fairness challenges. 




Figure. 1 Conceptual Framework

Source: Researcher (2020)

\section{Methodology and Procedures}

\subsection{Research Design}

The type of research design employed under this study was descriptive. The major purpose of using descriptive research is description of the state of affairs as it exists at present.

\subsubsection{Sample design and Procedures}

Sodo City was purposely chosen among six administrative cities of wolaita zone, as a study area for this research. This is because major VAT registered firms were found in this city and its nearness and convenience to collect data in short time. Stratified sampling design was employed to stratify the business firms in to three strata such as service rendering firms (351), metal and wood work firms (219), textile and garment firms (176) in order to give chance according to their numbers. Then, simple random sampling technique was used to select the representative sample from each stratum.

Table 3. 1 Stratification of the population

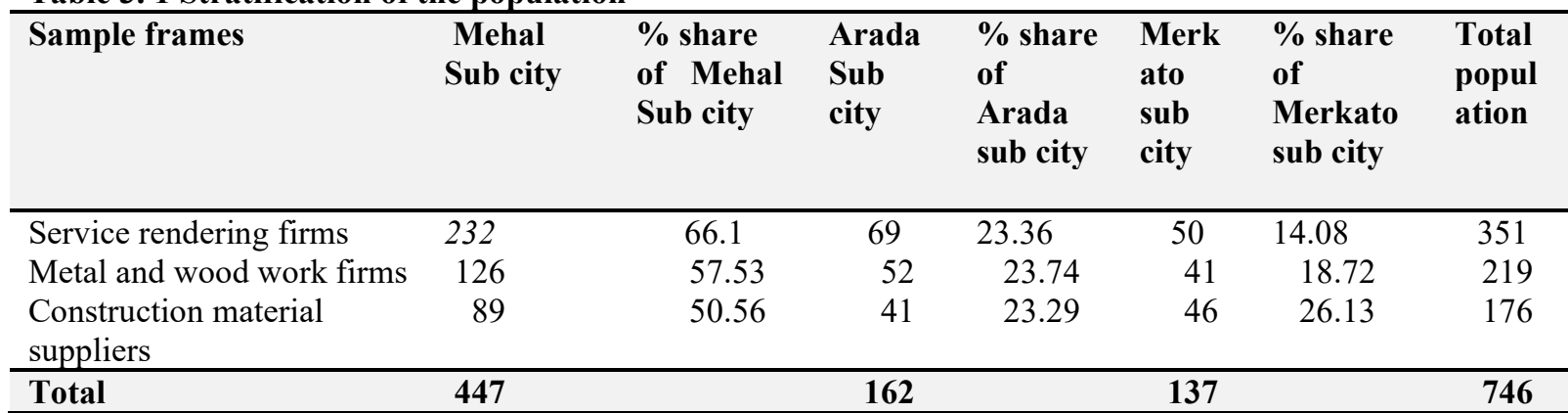

Source: Field Survey Result 2020

3.1.2. Sampling size

The sample size of VAT registered firms in three sub city was determined by a simplified formula provided by Yamane $(1967: 258)$ in order to determine the required sample size at $95 \%$ confidence level, degree of variability is 0.5 and with the level of precision of $5 \%$ is

$$
\mathbf{n}=\frac{\mathbf{N}}{1+\mathbf{N}}\left(\mathrm{e}^{2}\right)
$$

Where ' $n$ ' is sample size (required responses), $N$ is the population size (VAT registrant Tax payers) and 'e' is the level of precision (margin of error).

The sampling frame for VAT registrant taxpayers was the registration list of tax payers in the Sodo city 
consists of 746 VAT payers at time of field survey is used as a total population. By using the above formula, we have

$$
\mathrm{n}=\frac{746}{1+746(0.05)^{2}}=260
$$

\subsection{Types and sources of data}

In this study, the researcher used both primary and secondary data. The primary data obtained from three different populations. Whereas, the secondary data were collected from Sodo City Revenue Authority and from published and unpublished reports, documents and website.

\subsection{Data collection Instruments}

\subsubsection{Questionnaires Design}

The study designed the survey of personally administered questionnaires in order to determine challenges that affect the performance of Value added Tax administration of the authority of the service rendering firms such as hotels, cafés and restaurants, metal and wood working firms and constructions material supplying firms across the three sub cities. Anonymised persons were asked to express their feelings about VAT and their idea was expressed in boxes.

\subsection{Reliability and Validity of the Instruments}

Reliability concerned with the consistency of measures (Bless and Higson-Smith,1995) emphasized that the level of an instrument's reliability is dependent on its ability to produce the same score when used repeatedly (Babbie and Mouton, 1998).

As Bryma and Bell (2003), stated that the Cronbach's Alpha result of 0.7 and above implies acceptable level of internal reliability. To meet consistency reliability of the instrument, the questionnaires was distributed to 10 individuals who are VAT registered organizations and Cronbach's alpha was found to be 0.784 which is above 0.7 .

Reliability test result of the questionnaire

\begin{tabular}{|l|l|}
\hline Cronb.ach's Alpha & N of Items \\
\hline 0.784 & 10 \\
\hline
\end{tabular}

Validity on the other hand refers to whether an instrument actually measures what it is supposed to measure, given the context in which it is applied (Babbie and Mouton, 1998; Bless and Higson-Smith, 1995). To assure validity, questionnaires were designed on the basis of earlier research papers' questionnaires and review of related literatures.

\subsection{Data Analysis}

To comply with the objective, descriptive statistics were used. Descriptive statistics was preferred in order to reduce the data in to a summary format by tabulation. The Statistical Package for Social Science (SPSS) version 16 was used to analyze the data obtained from primary sources.

\section{Results and Discussion}

\subsection{Questionnaire response rate}

Two hundred sixty questionnaires were distributed to service rendering firms such as hotels, cafés and restaurants, metal and wood working firms and constructions material supplying firms across the three sub cities. Out of which 240 were completed and retrieved successfully, representing $92.3 \%$ response rate.

\subsection{Demographical characteristics of VAT registered firms}

The descriptive analysis was used to look at the data collected and to describe the demographic factors for additional explanation. The demographics factors used in this article were sex, age and education qualifications of the respondents. 
Table 4. 1 Demographical characteristics of VAT registered firms

\begin{tabular}{|ll|r|r|}
\hline & Demographic characteristics & Frequency & Percent \\
\hline Sex & Male & 146 & 60.84 \\
& Female & 94 & 39.16 \\
& Total & $\mathbf{2 4 0}$ & $\mathbf{1 0 0 . 0 0}$ \\
& 20-30 years & 115 & 47.92 \\
Age & 95 & 39.58 \\
& 4l-40 years & 30 & 12.5 \\
& Total & $\mathbf{2 4 0}$ & $\mathbf{1 0 0 . 0 0}$ \\
& Elementary school(1-8) grade & 42 & 17.5 \\
Secondary school(9-12) grade & 101 & 42.08 \\
Diploma & 59 & 24.58 \\
& First degree & 38 & 15.83 \\
& Total & 240 & 100.00 \\
\hline
\end{tabular}

Source: Field Survey Result 2020

Table 4.1 illustrates that most of the respondents were males $(60.84 \%)$ while $39.16 \%$ were females. This shows that major part of VAT revenue collection in the city was activated by males.47.92\% are the age of 20-30 years old, followed by respondent at the age between 31-40 years old with $39.58 \%$, and the remaining of the respondents of $12.5 \%$ were at the age of 41 years and above.(Table 1) From the above data we can say that larger portion of VAT revenue collection activities were done by youth people with the age of below 30 followed by the age of 31-40. As indicated in the table 4.1. $15.83 \%$ hold a first degree. In the other way, $24.58 \%$ were diploma holders, while $42.08 \%$ of the respondents achieved secondary education. $17.50 \%$ achieved primary education. From the above data we can see that even though there were diploma and degree holders to some extent most of the respondents of VAT registered firms were attended secondary education and this also indicate that VAT revenue administration process were done by low educated persons.

\subsection{Analysis of performance of VAT registered firms}

In this section the paper discusses and analyzes the factors the affect the administration and collection of VAT performance of three categories of business firms' categories which are service rendering firms, metal and wood working industries and Construction material supply firms that are existing in wolaita sodo city, Ethiopia. Based on the above information the researcher analyzed the as follows.

Table 4.2 Awareness on VAT

Do you have enough knowledge about VAT?

\begin{tabular}{|c|c|c|c|c|c|c|c|}
\hline & \multirow[b]{2}{*}{ Responses } & \multicolumn{2}{|c|}{$\begin{array}{c}\text { Service rendering } \\
\text { firms }\end{array}$} & \multicolumn{2}{|c|}{ Metal and wood work firms } & \multicolumn{2}{|c|}{ Construction material suppliers } \\
\hline & & Frequency & Percent & Frequency & Percent & Frequency & Percent \\
\hline \multirow[t]{3}{*}{ Valid } & Yes & 41 & 34.16 & 22 & 30.55 & 28 & 58.33 \\
\hline & No & 79 & 65.84 & 50 & 69.45 & 20 & 41.67 \\
\hline & Total & 120 & 100 & 72 & 100 & 48 & 100 \\
\hline
\end{tabular}

Source: Field survey data, 2020

As we can see from the above table, 240 respondents that are VAT registered organizations asked about their knowledge regarding VAT. Among those business organization that are engaged in service rendering $65.84 \%$ of firms do not have enough knowledge about VAT or poor knowledge of VAT and $34.16 \%$ have better understanding or knowledge on VAT. It is also referred in the table that metal and wood work organization and construction material suppliers have no knowledge on VAT $(69.45 \%$ and $41.67 \%)$. So, we can say that almost $50 \%$ of respondents have poor knowledge about VAT. Tax education and awareness creation opportunities and different types of training should be given to all public in order to increase the awareness level of the people and then to increase the performance and efficiency of VAT income collection. The idea is supported by Ahmad, M.A.R., Ismail, Z. and Halim, H.A., 2016, Awareness and perception of taxpayers towards goods and services tax (GST) implementation. According to focus group discussant from the service rendering firms' one respondent (SR1) reported us" he was punished by the authority not understanding the principles, rules and regulations of VAT. He highly complained the authority officers and managers for not training all VAT payers before new guidelines were applied. So SR1 reported that there is lack of awareness about VAT and its 
applications." ,

Table 4.3 Customers reasons for paying VAT

Do you know why you pay VAT?

\section{Responses}

As national responsibility

Because the government forced me to pay

Total

Source: Field survey data, 2020 believed that they pay VAT because the government forced them to pay. Whereas $38(31.67 \%)$ of service rendering institutions, $26(36.11 \%)$ of metal and wood producing organizations $22(45.83 \%)$ of construction suppliers perceive that they VAT as national responsibility. In general, the above statistical data shows that the greater part of the respondents have relatively they don't understand why they are paying VAT.

Table 4.4. The reasons why people evade VAT

\begin{tabular}{|c|c|c|c|c|c|c|c|}
\hline \multicolumn{8}{|c|}{ Do you know the reasons why peoples evade VAT? } \\
\hline & \multirow[b]{2}{*}{ Responses } & \multicolumn{2}{|c|}{ Service rendering firms } & \multicolumn{2}{|c|}{ Metal and wood work firms } & \multicolumn{2}{|c|}{$\begin{array}{c}\text { Construction material } \\
\text { suppliers }\end{array}$} \\
\hline & & Frequency & Percent & Frequency & Percent & Frequency & Percent \\
\hline \multirow{5}{*}{ Valid } & Lack of awareness & 42 & 35 & 26 & 36.1 & 20 & 41.67 \\
\hline & Intentional & 46 & 38.33 & 14 & 19.4 & 10 & 20.83 \\
\hline & Negligence & 8 & 6.67 & 12 & 16.7 & 6 & 12.5 \\
\hline & $\begin{array}{l}\text { Lack of ability to } \\
\text { pay }\end{array}$ & 24 & 20 & 20 & 27.8 & 12 & 25 \\
\hline & Total & 120 & 100 & 72 & 100 & 48 & 100.00 \\
\hline
\end{tabular}

Source: Field survey data, 2020

According to above table the respondents of Service rendering firms reasoned out, intentional $(38.33 \%)$, lack of awareness on VAT (35\%), lack of ability to pay $(20 \%)$, and negligence $(6.67 \%)$ behavior. Metal and wood working institutions responded that lack of awareness (36.1\%), lack of ability to pay (27.8\%), and intentional $(19.4 \%)$ and construction material suppliers responded that lack of awareness $(41.67 \%)$ followed by lack of ability to pay (25\%). According to the above table lack of awareness and ability to pay followed by intentional are the major causes for VAT evasion in the city. This analysis is argued by Trandafir, A., 2017 in his study of Value-Added tax evasion methods and the dimension of informal economy. One of our respondents who is categorized under construction material suppliers (CMS1) reported that 'the reason why business firms evading Value added Tax (VAT) because of the government bodies show them action of aggression's and feeling of over controlling, their approach was not convenient to the tax payers so that most of VAT registered firms (payers) were intentionally evade Value Added Tax."

Table 4.5 Knowledge on cash registering machines and its operation

\begin{tabular}{|l|r|r|r|r|r|r|}
\hline & \multicolumn{2}{|c|}{ Service rendering firms } & \multicolumn{2}{|c|}{ Metal and wood work firms } & \multicolumn{3}{|c|}{ Construction material suppliers } \\
\hline Responses & Frequency & Percent & Frequency & Percent & Frequency & Percent \\
\hline Valid Yes & 48 & 40 & 32 & 44.44 & 22 & 45.83 \\
No & 72 & 60 & 40 & 55.56 & 26 & 54.17 \\
Total & 120 & 100 & 72 & 100 & 48 & 100.00 \\
\hline
\end{tabular}

Source: Field Survey Result 2020

According to the above table, the managers of each institutions were asked about electronic cash register machines operation and replied that Service rendering (60\%), metal and wood work firms (55.56\%) and construction materials suppliers $(54.17 \%)$ have no enough knowledge on VAT machines operations which is using as a tool to collect VAT. On the other hand $40 \%$ of service rendering firms, $44.44 \%$ of metal and wood work firms, and $45.83 \%$ of Construction material suppliers replied they have ability to use and operate it. As revealed in the above table 4.7. the bulk of the respondents answered that they do not have adequate understanding on electronic cash register machine operation. One of the metal working firm's (WM1) respondent informed as his business was highly affected by electronic cash registers (ETRs) usage and its operation. Due to misunderstanding and lack of ETRs operation knowledge the respondent caused to 
punishment by the authority. Our respondent highly pointed the finger at government officials of the city. He said that his business was going on to fail and this made his mind to be distorted.

Table 4. 6 Fairness of registration and selection for VAT

\begin{tabular}{lrrrrrr}
\hline & \multicolumn{6}{l}{ Do you believe that process of registration and selection for VAT is fair? } \\
\hline & \multicolumn{2}{l}{ Service rendering firms } & \multicolumn{2}{c}{ Metal and wood work firms } & \multicolumn{2}{c}{ Construction material suppliers } \\
Responses & Frequency & Percent & Frequency & Percent & Percent & percent \\
Fair & 26 & 21.67 & 34 & 28.33 & 8 & 16.67 \\
Unfair & 90 & 75.00 & 56 & 77.77 & 40 & 83.33 \\
No idea & 4 & 3.33 & 0 & 0.00 & 0 & 0.00 \\
\hline Total & $\mathbf{1 2 0}$ & $\mathbf{1 0 0 . 0 0}$ & $\mathbf{7 2}$ & $\mathbf{1 0 0 . 0 0}$ & $\mathbf{4 8}$ & $\mathbf{1 0 0 . 0 0}$ \\
\hline
\end{tabular}

Source: Field survey data, 2020

As it indicated from above table, $75 \%$ of service rendering firms, $77.77 \%$ of metal and wood work firms and $83.33 \%$ of construction material suppliers replied that the process of registration and selection for VAT was unfair. On the other hand $21.6 \%$ of service rendering firms, $28.33 \%$ of metal and wood work firms and $16.67 \%$ of construction material suppliers replied the of registration and selection process was fair. We can conclude that the registration and selection process for VAT majorly unfair.

Table 4. 7 Audit and enforcement on VAT revenue collection

How do you evaluate the audit and enforcement system of the tax authority regarding VAT?

\begin{tabular}{|c|c|c|c|c|c|c|c|}
\hline \multirow[t]{2}{*}{ Item } & & \multicolumn{2}{|c|}{$\begin{array}{l}\text { Service rendering } \\
\text { firms }\end{array}$} & \multicolumn{2}{|c|}{$\begin{array}{l}\text { Metal and wood } \\
\text { working firms }\end{array}$} & \multicolumn{2}{|c|}{$\begin{array}{c}\text { Construction material } \\
\text { suppliers }\end{array}$} \\
\hline & & Freq & percent & Freq & percent & Freq & Percent \\
\hline \multirow{2}{*}{$\begin{array}{l}\text { Lack clarity and transparency for } \\
\text { selection }\end{array}$} & Yes & 100 & 83.33 & 50 & 69.44 & 40 & 83.33 \\
\hline & No & 20 & 16.67 & 22 & 30.56 & 8 & 16.67 \\
\hline \multirow{2}{*}{$\begin{array}{l}\text { Employees lack experience to tax } \\
\text { audit }\end{array}$} & Yes & 80 & 66.67 & 46 & 63.89 & 20 & 41.67 \\
\hline & No & 40 & 33.37 & 26 & 36.11 & 28 & 58.33 \\
\hline \multirow[t]{2}{*}{ Tax Audit finding discouraging } & Yes & 112 & 93.33 & 40 & 55.55 & 44 & 91.67 \\
\hline & No & 8 & 6.67 & 32 & 44.45 & 4 & 8.33 \\
\hline Total & & 120 & 100 & 72 & 100.00 & 48 & 100.00 \\
\hline
\end{tabular}

Source: Field Survey Result 2020

In respect of VAT audit and enforcement in the towns, tax registered firms were asked whether their office clarity and transparency in VAT auditing and enforcement or not. Out of 240 VAT registered firms, $83.33 \%$ of service rendering firms, $69.44 \%$ of Metal and wood working firms and $83.33 \%$ of Construction material suppliers agreed that there exists a problem on clarity and transparency of VAT customers' selection for Auditing. $66.67 \%$ of service rendering firms, $63.89 \%$ of metal and wood work firms, and $41.67 \%$ of construction material suppliers replied that the employees of the revenue office lack experienced personnel's on audit of VAT tax and inversely $33.37 \%, 36.11 \%$, and $58.33 \%$ of the respective VAT registered firms confirmed that they denied that the office employees have experience. According to audit finding the three categories of VAT firms are not happy by the authority's Auditing system. From the above data we can analyze that the problem of audit and enforcement is the major challenge for tax administration in the city.

Table 4.8 Administration simplicity

\begin{tabular}{|c|c|c|c|c|c|c|c|}
\hline \multirow[t]{2}{*}{ Item } & \multirow[t]{2}{*}{ Response } & \multicolumn{2}{|c|}{$\begin{array}{l}\text { Service rendering } \\
\text { firms }\end{array}$} & \multicolumn{2}{|c|}{$\begin{array}{l}\text { Metal and wood } \\
\text { working firms }\end{array}$} & \multicolumn{2}{|c|}{$\begin{array}{c}\text { Construction } \\
\text { material suppliers }\end{array}$} \\
\hline & & Freq & percent & Freq & Percent & Freq & Percent \\
\hline \multirow{2}{*}{$\begin{array}{l}\text { Lack of clear division of } \\
\text { duties and responsibilities } \\
\text { among employees }\end{array}$} & Yes & 62 & 51.67 & 38 & 52.78 & 28 & 58.33 \\
\hline & No & 58 & 48.33 & 34 & 47.22 & 20 & 41.67 \\
\hline \multirow{4}{*}{$\begin{array}{l}\text { Poor organization and } \\
\text { ineffective communication } \\
\text { High turnover of managers } \\
\text { and employees }\end{array}$} & Yes & 60 & 50 & 56 & 77.78 & 30 & 62.5 \\
\hline & No & 60 & 50 & 16 & 22.22 & 18 & 37.5 \\
\hline & Yes & 68 & 56.67 & 40 & 55.56 & 20 & 41.67 \\
\hline & No & 54 & 43.33 & 32 & 44.44 & 28 & 58.33 \\
\hline
\end{tabular}

Source: Field Survey Result 2020 
Among 240 respondents, $51.67 \%$ of service providing organizations, $52.78 \%$ of metal and wood working firms and $58.33 \%$ of Construction material suppliers replied that the organization lack of clear division of duties and responsibilities among employees. It is stated that $50 \%$ of service providing firms, $77.78 \%$ of metal and wood working firms, $62.5 \%$ construction material suppliers agreed that there exists poor organization and ineffective communication with tax payers. Moreover, $56.67 \%$ of service providing firms, $55.56 \%$ of metal and wood working firms and $41.67 \%$ of construction material suppliers replied that there was high turnover of managers and employees in the organization. Due to above mentioned administrative issues the organization lacks administrative simplicity. The concept is also supported by Zeleke, T.G., 2018. An assessment of Value added tax administration practices.

Table 4.9 Service delivery and its flexibility on VAT administration

\begin{tabular}{|c|c|c|c|c|c|c|c|}
\hline \multirow[t]{2}{*}{ Item } & \multirow[t]{2}{*}{ Response } & \multicolumn{2}{|c|}{$\begin{array}{c}\text { Service } \\
\text { rendering }\end{array}$} & \multicolumn{2}{|c|}{$\begin{array}{l}\text { Metal and wood } \\
\text { work firms }\end{array}$} & \multicolumn{2}{|c|}{$\begin{array}{c}\text { Construction } \\
\text { material suppliers }\end{array}$} \\
\hline & & Freq & Percent & Freq & Percent & Freq & Percent \\
\hline \multirow[t]{2}{*}{ Less customer relationship and handling. } & Yes & 82 & 68.33 & 56 & 77.78 & 40 & 83.33 \\
\hline & No & 38 & 31.67 & 16 & 22.22 & 8 & 16.67 \\
\hline \multirow[t]{2}{*}{ Not flexible and on time } & Yes & 110 & 91.67 & 60 & 83.33 & 44 & 91.67 \\
\hline & No & 10 & 8.33 & 12 & 16.67 & 4 & 8.33 \\
\hline \multirow[t]{2}{*}{ Less innovative and pioneering } & Yes & 62 & 51.67 & 56 & 77.78 & 30 & 71.42 \\
\hline & $\mathrm{No}$ & 58 & 48.33 & 16 & 22.22 & 24 & 27.58 \\
\hline
\end{tabular}

Source: Field Survey Result 2020

From Table 4.9 we can refer that there is less customer relationship and handling which is verified by $68.33 \%, 77.78 \%$ and $83.33 \%$ of service rendering, metal and wood work firms and construction materials suppliers respectively that is seemed to be the major contributing challenge to VAT income administration. The respondents also confirmed that the service delivery system is not flexible and on time and this is assured by representing $91.67 \%, 83.33 \%$ and $91.67 \%$ of the three categories of business firms in the city. Next to this, the office was less innovative and pioneering in service providing which is explained by $51.67 \%, 77.78 \%$ and $71.42 \%$.This work is similar to the idea of Owusu,(2006:478) analyzed that service delivery of the organization is one of the most influential factor in order to increase the customers' satisfaction. One of our focus group member (SR2) responded that the service delivery of the authority is not flexible, not on time, it was tedious, and the officers differentiate (separate) customers from customers, their communication style is not good for business men's.

\section{Conclusion and Recommendations}

\subsection{Conclusions}

This research proves that there are different challenges that significantly affect Soddo City Revenue administration and Value added tax administration processes. The demographic factors such as sex, age and educational backgrounds made the challenge for VAT tax administration. The challenges like lack of awareness of taxpayers, less usage of tax technology especially less usage of electronic tax register machines, increasing rate of different VAT evasion activities by business firms and the consumers, less VAT audit and enforcement, Service delivery of the organization, poor VAT administration and unfairness of registration and selection customers for VAT tax payment.

\subsection{Recommendations}

The following recommendations are suggested to improve the VAT revenue administration challenges in Sodo city in wolaita zone.

The recommendations to the authority are:

1. The City administration should carry out a regular awareness creation programs to update the business firms and for the community about Value Added Tax.

2. The authority supposed to the endless follow up the existing business organizations to use Electronic tax register machines and should train business organizations to be registered those who did not registered firms for VAT.

3. The main reason for this according to this study is lack of awareness about VAT, ability to pay and negligence of business enterprises. However, to sustain the VAT system as a good means to raise government revenue, the Sodo city administration revenue authority should take actions such as: educate the taxpayers about the rules and regulations of VAT constantly, delegate the tax authority to three sub cities. 
4. Strong audit and enforcement is very important element to enhance VAT revenue administration and to reduce tax evasions. So, the authority has to establish effective audit and enforcement mechanisms.

5. The process of VAT registration of the authority should be fair, smooth and easy for taxpayers. The city has to improve poor administrations processes and create conducive environment for taxpayers.

6. In order to continue with good service delivery, the authority should mainly focus customers (taxpayers) satisfaction, to do this the authority focus on customer relation and handling, use innovative and pioneering customer satisfying activities in its service delivery to make work process transparent and ensure accountability in public service delivery.

The recommendations to public are:

The business firms supposed to follow the existing VAT rules and regulations and enhance the culture of Value added tax paying as a sign of modern thinking, the public consider paying tax as a means of directly or indirectly putting one's own contribution on changing the life of each citizen and ought to start to work in cooperation with the authority in struggling against those enterprises that are not registered to VAT revenue.

\section{References}

- $\quad$ Ahmad, M.A.R., Ismail, Z. and Halim, H.A., 2016. Awareness and perception of taxpayers towards goods and services tax (GST) implementation. International Journal of Academic Research in Business and Social Sciences, 6(11), pp.2222-6990.

- Aker, J.C., 2017. Using digital technology for public service provision in developing countries. Digital Revolutions in Public Finance, p.201.

- Alm, J., Martinez-Vazquez, J. and McClellan, C., 2016. Corruption and firm tax evasion. Journal of Economic Behavior \& Organization, 124, pp.146-163.

- $\quad$ The Ethiopian Revenue minister annual report,2019

- Gupta, A. S. (2007) Determinants of tax revenue efforts in developing countries, IMF Working Papers 07/184, International Monetary Fund.

- Gupta, L. and Agarwal, A., 2017. Awareness and Understanding of GST among Indian Consumers: An Empirical Study. VISION: Journal of Indian Taxation, 4(2), pp.102-111.

- Jalata, D. M. (, 2014). "The Role of Value Added Tax on Economic Growth of Ethiopia " research Journal, vol.1.

- Karanja, M. N. (, 2012), Internal Factors affecting Performance of Collection of Local Value added tax revenue, Keniyata University .

- Kayanga, L. (2007). Tax Policy Challenges Facing Developing Countries Ontario, Queen's University Kingston, Canada.

- Keen, M. and Lockwood, B. (2010) The value added tax: Its causes and consequences, Journal of Development Economics, 92, 138-151.

- $\quad$ Lockwood, M. K. a. B. (, 2007). Value Added Tax: Its Caused and Consequences,. United Kingdom, The University of Warwick. Ph.D Thesis.

- Mahmoud Moeinadin, F. H., Azadeh Harandi (, 2014 ). "Identifying the Effective Factors for the Improvement of Tax Compliance." international journal vol $\mathbf{1 .}$

- Mamo, H. (2011). Implementation of Value added tax and its related problems in Ethiopia, Addis Ababa Univeristy.

- Mahesh C. Purohit (1993). Principles and Practice of Value Added Tax-Lessons for Developing Countries, Gayatri Publications, New Delhi.

- $\quad$ Mukherjee, S. and Rao, R.K., 2019. Value Added Tax and Informality: Determinants of Registration of Enterprises under State VAT in India. Margin: The Journal of Applied Economic Research, 13(1), pp.21-48.

- Omodero, C.O. and Dandago, K.I., 2019. Tax revenue and public service delivery: Evidence From Nigeria. International Journal of Financial Research, 10(2), pp.82-91.

- Parvez, M. n. a. K. (2012). "Effect Of Vat And Tax On Economy: An Analysis In The Context Of Bangladesh." vol 3.

- Thiripurasundari, K. and Divya, S.V., 2018. Public Awareness towards GST in Tenkasi taluk. Profession, 11, p.18.

- Pillai, G.K. (2003). VAT- Problems and Prospects of Adopting Value Added Tax, Jaico Publishing House, Bombay.

- Taye, Y. (2011). The impact of Electronic Tax Register on Value Added Tax. Accounting and Finance, Addis Ababa University

- Sanusi, S., Firdaus, M.A., Noor, R.M., Omar, N. and Sanusi, Z.M., 2018. Technology on Goods and Services Tax Compliance Among Small Medium Enterprises in Developing Countries. Advanced Science Letters, 24(7), pp.5461-5465.

- Sebhat Tebebu, W. and Chanie Yitbarek, M., 2020. Implementation of value added tax and it's challenges: 
evidence from Bench Sheko zone, SNNPR, Ethiopia.

- $\quad$ SUNTORO, A.A. AND TJEN, C., 2017. THE CHALLENGES OF IMPLEMENTING VALUE-ADDED TAX ON E-COMMERCE TRANSACTIONS IN INDONESIA.

- $\quad$ Tamrie Atnafu, W., Gebretsadik Kalayou, G. and Gezae Huluf, A., 2019. Perceptions of Value Added Tax Filing and Invoicing Compliance in Ethiopia: The Case of Three Federal Branch Offices in Addis Ababa.

- Trandafir, A., 2017. Value-Added tax evasion methods and the dimension of informal economy in Romania. Economics, Management and Financial Markets, 12(2), p.160.

- Tulu, L.(2007) Determinants of Taxpayers' Voluntary Compliance with Taxation, Addis Ababa University MBA Thesis

- Wuyah, Y.T., Aku, Y.Y. and Ahmad, M.D., 2018. Impact of Tax Audit and Investigation on Value Added Tax Generation in Kaduna State. American Journal of Business and Society, 2(3), pp.52-56.

- Wollela Abehodie Yesegat, (2008), Value Added Tax Administration in Ethiopia: A Reflection of Problems, eJournal of Tax Research, vol. 6, no. 2, pp. 145-168

- Wolaiata Zone Revenue Authority Annual Report, 2018.

\section{Acknowledgement}

The present researchers kindly acknowledges all this study participants Sodo city administration office employees for their active participation and good will in providing all necessary information based on authors request. 